Peter Zieme

\title{
The Layman İndu and an Old Uighur Poem
}

Abstract: Edition of an Old Uighur poem preserved on the verso side of SI 4959 (Kr I 18) of the Serindia Collection of the Institute of Oriental Manuscripts. The fragment contains twelve stanzas à four lines. The contents is difficult to define, It is assumed that stanzas I to VI refer to an unnamed young boy who may be a Buddhist novice, while stanzas VII to XII emphasise the importance of doing punya, good deeds. The layman İndu is presented as a model. In stanza IX he vows to encounter with Maitreya expressed in an indirect way. Similar verses are known from Maitreya poems. The paper presents a full edition of this fragment with some notes on problematic words and phrases.

Key words: Old Uighur, alliterative poem, Buddhist culture, acquiring punya, layman (upāsaka) Indu.

\section{Some introductory words}

SI $4959\left(\operatorname{Kr~I~18)^{1}}\right.$ is a fragment of a Chinese scroll of the 金剛般若 波羅蜜經論 Jingang boreboluomi jing lun ${ }^{2}$. It was cut and used for writing the Old Uighur text on the empty verso side of the paper. A similarly shaped leaf (SI 4051 (4bKr 56)) from the same Chinese text ${ }^{3}$, but necessarily not from the same scroll, bears on its verso side an Old Uighur Maitreya text ${ }^{4}$. The Uighur script differs from that of the first leaf. It is not clear whether both fragments originally were parts of a bound booklet or not, but, clearly, the texts are different, too. Thus we have to conclude that both fragments originated under different circumstances, by different authors as well as by different scribes.

(C) Peter Zieme, Berlin Brandenburg Academy of Sciences and Humanities

${ }^{1}$ IOM Krotkov Collection. I express my thanks to I.F. Popova for the permission to publish the fragment, to A. Turanskaya for sending me its digital image that is attached at the end of this paper.

${ }^{2}$ T.XXV.1511.796c21-797a04.

${ }^{3}$ T.XXV.1511.790c20-791a03.

${ }^{4}$ Not metrical. 
It is not easy to characterise the Old Uighur text of SI 4959 in toto. It consists of 12 stanzas of four verses composed in the usual strophic alliteration mode. One can distinguish two parts. Stanzas I to VI all end in täginür apparently referring to a young boy who may be a Buddhist novice. This first part concludes with the question "How can one explain it?" In the second part from stanza VII to XII emphasis is laid on doing punya. The layman (upase < Skt. upāsaka) İndu is presented as a model. In stanza IX he vows to encounter with Maitreya expressed in an indirect way. Similar verses are known from Maitreya poems. ${ }^{5}$ In stanza XI other lay people are mentioned if the interpretation is correct: Sujāta and Sukha Tärim, both with names of Sanskrit origin. The author mentions them apparently as believers who fulfil punya deeds. With the last stanza (XII) probably a sermon started which expounds some essential Buddhist tenets like the unsteadiness of the body and the turbulences in the samsāra.

As a whole it is a Buddhist poem, but refers to some strange things in a very densely composed language. I am aware that my translation is not always matching the intention of the author. Some readings remain problematic.

\section{Transliteration}

01 mwywm tyn்m'dy k'nč 'wqln . mwñwä čwp kwylm'z twyz lwqln .. mwny t'k qylw t'kynsr

02 mwnk'dqw kwylkw sv t'kyñwr ' ywd'n q'pčwq̈y ywmwrdä' čwč'ky ywl "smys

$03 / / / d^{\prime} k y$ ywmäy t' t'nkl' q̈w sv t'kyñwr ' twyyn kwyrklwk 'rsl'n t' twdčy 'ysl'kw

04 'ysyk twr' pylyky č'q k' ňč twdwp sysynm'z t'k t'kynwr ' pyr'dy pylk'

05 pylyky 'nkl'mys pylk' pntyd lr nynk nwm l'ryn pylyksy sy kwyč'dmys pyčyn k' 'y'

06 pyt'dy 'wydkwṅmys t'k t'kynwr - 'rsl'n t'yy nynk m'n̈kyn t' 'rwq tylkw

07 'wydkwniwp ' $d$ ' t' t'kmys t'k t'kynwr " 'yryndy lyk mwny t'k 'ys lr nynk

${ }^{5}$ Cp. BT III. 
08 'ysd'my p'rkyn pylyp 'wk 'ydy s'črwqswz 'ys pwlm'q 'yñdw 'wp'sy tyn

09 tylt'q lyq t'kyniwr n'd'kyn typ tysr ' kym 'wl

10 kyčyk yykyt y's yndynp'rw . kysy t' kyn̈k' pwlm’dy kyč' kwyñdwz tydylyp

11 t'kynyp kyn்kwrw pwyn் lyq 'ys lr t' y'r'dynd'čy " ' 'wyk q'àk twydwn்yn 'wyčwrm' dyn

12 'wyklydw ' z' twdt' čy . 'wyslwnčw k' d'ky 'dkwlwk 'yslryk 'wysm' dyn

13 qyld'čy twyswd lwk " 'ylky t'ky qylyñč l'ryn 'wyčwrwp 'ydyp'dry

14 tnkry p'ldkwrmys 'ydwq 'wrdw t' twrqw kwysws lwk 'yndw 'wp'sy '

15 ' 'čwk y'rwq pylyky ' z 'ysnk' k'sd'my ' dyn k' 'wyzk' pyr t'k 'rm'k y

16 ' 'nwp'm' syz q' ywl'sy ' swč' dyt' 'dkw lwk 'ys lr t' ' vryslyk swrm' $\ddot{q}^{\prime} m q$

17 pwy'n t' twyswd lwk swk' t'rym pyrl' 'ykykw 'ynč' typ swysl'sw (?)

18 t'kynmys l'r ' p'slä syz 'wswn s'nsr tyn p'rw p'ssyz 't'wyz ///

19 p'rm'nw l'r t'k t'ksynyp p's syz [...]

\section{Transcription, translation and notes}

I

${ }^{01}$ moyum tınmadı känč oglan .

munuk čöp külmäz tüz luglan ..

munı täg kılu tägins(ä)r

${ }^{02}$ muyadgu külgü sav täginür •

Confused $^{6}$, did not rest the young boy,

disturbed ${ }^{7}$, rubbish $^{8}$, not-laughing, equal ${ }^{9}$ nonsense $^{10}$ :

Doing like this

are things ${ }^{11}$ to wonder on and to laugh at.

\footnotetext{
${ }^{6}$ moyum "confused" (ED 773a).

${ }^{7}$ Derived form mun- < bun- ED 348, munuk 'mentally confused' (OTWF 231, 802).

8 čwp čöp i.a. "rubbish" (ED 394a).

${ }^{9}$ twyz tüz "flat, equal" (ED 571b), or töz "root" (ED 571a)?

${ }^{10}$ luglan cp. BT XXV, 0741 kırt luvlan "sinnlos"; BT XIII.13.98 luvlan kartı "id." (cp. sačuk luglan "id." in a text edited by M. Ölmez, cp. ÖLmEZ 1998, 277-278). Initial $l$ - suggests a foreign origin, but the variants $-\mathrm{g}-/ / \mathrm{-v}$ - point to the opposite. As suggested in BT XIII, it is probably an onomatopoetic formation. A further example occurs in a medical text (IOM SI 4133 recto 10) as a name of a disease: luvlan agrig.

${ }^{11}$ Or "words"?
} 
yudan kapčuk1

yumurtga čäčäki

yol azmıš ${ }^{03}[$ ör]däki

yumkita tạlagu s(a)v täginür "

A small bag ${ }^{12}$ of yudan ${ }^{13}$,

a flower ${ }^{14}$ of an egg,

a duck (? $)^{15} \operatorname{lost}^{16}$ one's way

all (of these are) things ${ }^{17}$ most astonish-able.

\section{III}

toyın körklüg arslanta

tutči išlägü ${ }^{04}$ išig

törä biligi čak känč

tutup sezinmäz täg täginür "

For $^{18}$ the lion of a monk's appearance ${ }^{19}$

\footnotetext{
${ }^{12}$ kapčuk "small bag" (ED 581b).

${ }^{13}$ The word ywd'n can be read in different ways like yodan/yudan, yödän/yüdän. If one thinks of a variant of yodun (ED 892a) one encounters the difficulty that yodun is not used as a single word, it is attested only in the compound yok yodun "destroyed". One expects here also something as a material thing. The next candidate could be yatan "a wooden bow" (ED 892a) which could fit to kapčuk "case, a small bag". But the vowel -w- instead of -'- in the first syllable cannot be explained. If one suggests a yodicised form of a different word like odan/udan etc, the problems are similar. The light solution would be "the bag of a wooden bow", but in that compound there is no contradiction that the whole strophe aims at.

${ }^{14}$ čwč ky ? Unfortunately, the spelling is not clear: As the second letter can be nothing else than -w-, it is nearly impossible to interpret it as a variant of čečäk "flower", but there is no obvious word like čöc̆äk or čüc̆äk. The modern Uighur word čöčäk < čörčäk "tale" (Jarring 76) cannot be taken into consideration here.

${ }^{15}$ The first three letters are not clearly distinguishable, they can be read as sth. like ' 1 ' or ' wl' or ' $y l$ ', while d'ky is very distinctly written. From the structure the final -y should be the possessive suffix and the preceding stem can end in -ädäk. Perhaps ördäk "duck" is not totally impossible assuming that a kind of contrast is meant. But still, what is a duck who lost its way?

${ }^{16}$ Spelled "smys, this shows that also other verbs are possible, as- or $a \check{s}$-, but in connection wit yol "way" $a z$ - is at least one of the candidates.

${ }^{17}$ The spelling is sk or rather sv. I assume $s(a)$ v "word(s)" or thing(s)".

${ }^{18}$ The translation of the suffix $+t a$ here is difficult.

${ }^{19}$ The expression toyın körklüg arslan is probably an expression for the Buddha. I refer here to the first line of an Old Uighur poem: toyın körklüg kesari arslan "Lion king of monk's appearance", cp. ZIEME 2013, 15. This poem contains also some very peculiar expressions and still unclear words.
} 
the deeds ${ }^{20}$ always to do

(according to the) Wisdom of the $\mathrm{Law}^{21} \mathrm{just}^{22}$ a young (boy)

should keep it and be one who does not doubt.

IV

piratya bilgä ${ }^{05}$ biligi änilmiš

bilgä p(a)nditlarnın nomların

biligsizi küčädmiš bečinkäyä

${ }^{06}$ bıtadı ötgünmiš täg täginür "

Through the dharmas of the wise panditas

who are bent ${ }^{23}$ (by) the prajñ $\bar{a}$ knowledge

the little ape ${ }^{24}$ whose nescience became strong

is as if he is uselessly retelling ${ }^{25}$ something.

V

arslan tayının mayınta

aruk tilkü ${ }^{07}$ ötgünüp

adata tägmiš täg täginür $\cdot 26$

Because of the gait $^{27}$ of a lion cub $^{28}$

${ }^{20}$ I emend to $i s ̌ i g$, but probably two letters stand at the beginning of the line so that another word might be meant here.

${ }^{21}$ twr'. This word can be read either tura/tora or tuna/tona or also with front vowels. One of such words which fits to the spelling is tura that has a similar meaning like tın "breath" (ED 512a), another tura is "breastwork" or "village, a place" (ED 531a). The more recent word törä "custom, law" (< törö ED 531b) is probably a better solution, although it is spelled twyrw otherwise. It would be most fitful in connection with bilig "knowledge": "knowledge of the law". But again, it is not at all sure that the word bilig "knowledge" was intended here.

${ }^{22}$ The spelling is unclear. The likeliest one is čak "exactly" (ED 404a). But perhaps we can compare it to BT III, 949 where we read: körünčlüg känčüki čak birlä "together with a young dancer of a performance" (cp. explanation by S. Tezcan), although D. Maue does not see in the pair (skt.) nada = (Old Uighur) čak (spelled ja-q) the word "dancer" (MAUE 1996, 16, n. to no. 36). Together with this new example čak känč one is inclined to see in all three attestations the same word. Additionally, cp. U 4445 line 3 čak är üküš türlüg kö[ ] (cp. ZIEME 2017, 2).

${ }^{23}$ änil- "to be bent" (cp. ägil- ED 106b), cp. UWV II, 144.

${ }^{24}$ bečink(ä)yä. The suffix $k(\ddot{a}) y a ̈$ is written $k y$ ' as it is usually the case. The initial letter $k$ is written in this ms. with a hook on the line, cp. käsdämi.

${ }^{25}$ Cp. ötgün- "to imitate, tell” (ED 52a).

${ }^{26}$ This stanza has only three verses. Since all other stanzas have four lines, one verse seems to be missing.

${ }^{27}$ Cp. may "gait" (ED 766b).

${ }^{28}$ The first letter of the word is unclear, but it is probably a $t$-, cp. tay "a one- or two-year-old foal" (ED 566b). As documented by I. Hauenschild, tay is used only for "foal" (HAUENSCHILD 2003, 201-202). Thus the reading and interpretation of arslan tayl remains dubious. 
an emaciated fox - while passing ${ }^{29}-$

is one as if he is getting into danger.

\section{VI}

erintilig munı täg išlärnin

${ }^{08}$ istemi bärkin bilip ök

idi sačuksuz ${ }^{30}$ iš bolmak

indu upasetın ${ }^{09}$ tıltaglıg täginür

Knowing the constant ${ }^{31}$ steadiness

of disgusting ${ }^{32}$ deeds like this

a totally un-scattered matter

is caused by the layman İndu!

nätägin tep tesär *

How is this?

kim ol

It is like this:

\section{VII}

${ }^{10}$ kičig yigit yašındınbärü .

kišitä kenkä bolmadı

kečä kündüz tıd1lıp ${ }^{11}$ täginip

kenürü buyanlıg išl(ä)rtä yaratıntačı •

For people from the days of child- and youth-hood

it never became too late ${ }^{33}$

(to be) one who night and day - (although) hindered ${ }^{34}-$

is extensively striving in punya deeds.

\section{VIII}

ög kạ tütünin öčürmädin

${ }^{12}$ üklitü asa tuttačı.

üzlünčükätägi ädgülüg išl(ä)rig

üzmädin ${ }^{13}$ k1ldačı tüšütlüg "

${ }^{29}$ Although clearly written with a dotted - $n$-, it might be a mistake for ötgür- "to pass" (ED 52b).

${ }^{30}$ The scribe manipulated the word in one or the other way wherefore it is difficult to give an exact spelling, but sačruksuz or sačuksuz is at least a possible reading.

${ }^{31}$ Spelled 'ysdymy istemi, cp. BT.XIII.13.135. Probably < Skt. sthema "continuance, duration" (MW 1265a).

32 'yryndylyk erintilig, cp. yerinti “disgusting” (ED 971a; LAUT 2011, 197; Li Gang 2016, 23, line 07; Mirkamal 2010, 5, line 11).

${ }^{33}$ This formation is unclear, if read kenkä it means "for later".

${ }^{34}$ This expression probably refers to the fact that human beings are often hindered by the kleśas to do good works. 
Not extinguishing the smoke $\mathrm{e}^{35}$ of mother and father

(rather) increasing and stimulating ${ }^{36}$ it, up to the end as a doer of good deeds practicing ${ }^{37}$ without interrupting.

\section{IX}

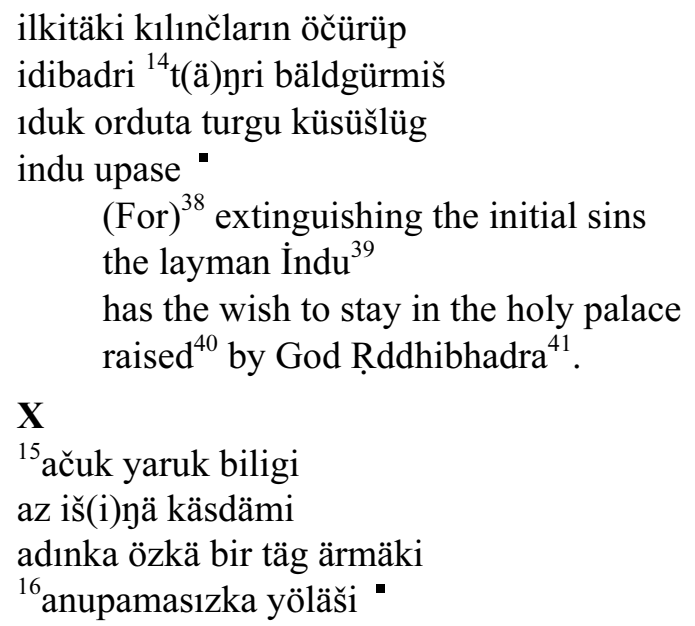

${ }^{35}$ The use of tütün in the sense of family bonds is an interesting feature of this popular text. In Kirgiz tütün has three meanings "smoke", "house, court", and "yurt" (JUDACHIN 286b-287a). The example tütüngö jarabagan jaman "a poor man without family" makes it clear that the "smoke-hole" of a yurt is a symbol of family life.

${ }^{36}$ The order in this biverb is more often as- üklit- "to foster and to increase", cp. UWV II, 84, tut- is here used as an auxiliary verb.

${ }^{37} \mathrm{~J}$. Wilkens reminded me of tüš̈̈t in the meaning of "habit, practice", cp. BT XXV, line 3713.

${ }^{38}$ Or: "(After)".

${ }^{39}$ The personal name İndu is attested in several Old Uighur texts (U 3398 recto 05 (in bold script): 'yñdw; DTS 219; Bai \& Matsui 2017, text I, 1.12). From this text it is impossible to gain any further information about this İndu. There is one İndu who belongs to the entourage of Qubilay's minister Munsuz, cp. no. 16 印都 yinduo = Chinese transcription of İndu (GABAIN 1976, 205). In later periods the same name was a new borrowing from Persian as Hindi etc. (cp. Rásonyi and Baski, p. 279a).

${ }^{40}$ For the verb bäldgür- "to develop, to raise", a "mixed" form of bälgür-t- and the rare verb cp. bäldür-t- (bältür-t-) a member of the biverb igit- bältürt- "to nourish, raise, develop" (ZIEME 2018, 219).

${ }^{41}$ Due to the alliteration Sanskrit *Rddhibhadra is here written idibadri, for other

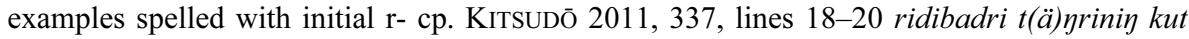
kolmakı üzä etilmiš tokuz älig sinlıg kat kat ilig kalıklıg d(a)rmaprasat "The Dharma-palace with forty-nine floors built by God R.ddhibhadra's vow”: translated from 四十九層重閣堂. 號日法殿處當陽. 牢度践提願力作. Cp. BT III, p. 98; BT XIII, p. 117, fn. 19.43. 
His clear and bright knowledge

is near ${ }^{42}$ to a deed of lust ${ }^{43}$.

His being equal to others and to oneself

is comparable to anupama ${ }^{44}$-less.

XI

sučadita ädgülüg išl(ä)rtä ävrišlig

sorma kam(a)g ${ }^{17}$ buyanta tüšütlüg

suka tärim birlä ikigü inčä tep

sözläšü ${ }^{45}{ }^{18}$ täginmišlär

About Sujāta ${ }^{46}$ behaving $^{47}$ in good deeds

- do'nt ask! $!^{48}$ - and practicing in all punya,

together with Sukha Tärim ${ }^{49}$ they both

were discussing each other.

\section{XII}

bašl(a)gsız uzun sans(a)rtın bärü

bašsız ät'öz ///

${ }^{19}$ parmanular täg tägzinip

baš/// [

Since the beginning-less long samsāra

a headless body [

Like atoms rotating

head[

].

${ }^{42}$ Spelled k'sd'my: the intial $k$ - is written with a hook leading to the line, the following hook is the aliph. The word kästämi/käsdämi is rare, it corresponds to 近 jin "near", e.g. WiLKENS 2017, 15v18 ölüm käsdämi.

${ }^{43} a z i \check{s}(i) \eta \ddot{a}$ "to the lust deed" is a conjecture, but perhaps it is better to read az ešikä "lustwoman". Among the examples of $a z$ in some cases it is regarded as female (UWN II, 2, p. 104), but so far the compound * $a z$ eši is not attested. On the other hand, one may also think of $a z$ "few".

${ }^{44}$ Skt. anupama "unvergleichlich" (SWTF I, 63b).

${ }^{45}$ Here one observes some kind of correction. If sözläš $\ddot{u}$ is the intended word, the verse is the only example of a distorted alliteration, as three verses have so-/su-.

${ }^{46}$ For Sujāta in the Buyan ävirmäk of the Old Uyghur Altun Yaruk sudur, cp. ZIEME 1991, 285.

${ }^{47}$ Cp. UWN II, 2, 347-348.

${ }^{48}$ sor-ma "do not ask!" (?).

${ }^{49}$ swk' may be interpreted as the Sanskrit term sukha "happiness" (cp. SWTF IV, 379). It is used as a female name corresponding to Turkic words like kut "happiness, charisma" or sävinč "joy". No other information about a person Suka Tärim is available. For tärim cp. ZIEME 2015. 


\section{Metrical structure}

The composition follows strictly the metrical pattern of the strophic alliteration, which is the main feature of Old Uighur poetry. In detail the structure is as follows:

$\begin{array}{lll}\text { I mo-/mu-: } 5+3(8) / 5+3(8) / 5+3(8) / 3+3+3(9) & 8+8+8+9 & \sum 8-9 \\ \text { II yu-: } 2+3(5) / 3+3 /(6) / 3+3(6) / 3+3+4(10) & 5+6+6+10 & \sum 5-10 \\ \text { III to-: } 4+3(7) / 5+2(7) / 5+3(8) / 5+4(9) & 7+7+8+9 & \sum 7-9 \\ \text { IV pi-/bi-: } 4+3+3(10) / 2+4+3(9) / 4+3+4(11) / 3+3+3(9) & 10+9+11+9 & \sum 9-11 \\ \text { V a-: } 5+3(8) / \ldots / 4+3(7) / 3+3+3(9) & 8+\ldots+7+9 & \sum 8-9 \\ \text { VI i-/1-: 4+3+3 (10) / 3+5 (8) / 5+3 (8) / 6-3-3 (12) } & 10+8+8+12 & \sum 8-12 \\ \text { VII ki-/ke-: } 4+5(9) / 5+3(8) / 4+3+3(10) / 3+3+3+5(14) & 9+8+10+14 & \sum 8-14 \\ \text { VIII ö-/ü-: } 5+4(9) / 5+3(8) / 6+3+4+(12) / 3+3+3(9) & 9+8+12+9 & \sum 8-12 \\ \text { IX i-/1-: 44+3 (11) / 4+5 (9) / 5+5 (10) / 2+3 (5) } & 11+9+10+5 & \sum 5-11 \\ \text { X a-: 4+3 }(7) / 4+4(7) / 3+4+3(10) / 6+3(9) & 7+7+10+9 & \sum 7-10 \\ \text { XI su-/su/su-/sö-: 4+3+3+3 }(13) / 4+3+3(10) 4+5+3(12) 3+4(7) & 13+10+12+7 & \sum 7-13 \\ \text { XII ba-/pa-: } 5+5(10) / ? / 5+3(8) / ? & 10+?+8+? & \sum 8-10\end{array}$

\begin{tabular}{|l|c|c|c|c|c|c|c|c|c|c|}
\hline Number of syllables per verse & 5 & 6 & 7 & 8 & 9 & 10 & 11 & 12 & 13 & 14 \\
\hline Number of verses & 1 & & 6 & 9 & 10 & 7 & 2 & 3 & 1 & 1 \\
\hline
\end{tabular}

The table thus shows that 11 verses have 9 syllables, this corresponds as a rule to three words consisting of three syllables each. A pattern which is not rare in Old Uighur poetry. This number is followed by verses of 8 syllables (8 times), of 10 syllables ( 7 times), and of 7 syllables ( 6 times).

\section{References}

Bai YUDONG and Matsui DAI 白玉冬 \& 松井太 2017: フフホト白塔のウイグル語題記銘文 „Old Uighur Inscriptions of the White Pagoda, Hohhot“. In: Studies on the Inner Asian Languages XXXI, 29-77.

BT III

Tezcan, Semih 1974: Das uigurische Insadi-Sütra, Berliner Turfantexte III. Berlin: Akademie-Verlag.

BT XIII

ZIEME, Peter 1985: Buddhistische Stabreimdichtungen der Uiguren, Berliner Turfantexte XIII. Berlin: Akademie-Verlag.

BT XXV

WiLkens, Jens 2007: Das Buch von der Sündentilgung. Edition des alttürkisch-buddhistischen Kšanti Kılguluk Nom Bitig I-II. Turnhout: Brepols Publishers. 
DTS

Drevnetjurskij slovar'. Leningrad, 1968.

ED

Clauson, Gerard 1972: An Etymological Dictionary of Pre-Thirteenth-Century Turkish. Oxford.

Gabain, Annemarie v. 1976:"Ein chinesisch-uigurischer Blockdruck". In: Tractata altaica Denis Sinor sexagenario optime de rebus altaicis merito dedicata. Wiesbaden: Harrassowitz, 203-210.

HAUENSCHILD, Ingeborg 2003: Die Tierbezeichnungen bei Mahmud al-Kaschgari. Eine Untersuchung aus sprach- und kulturhistorischer Sicht, Wiesbaden: Harrassowitz.

JARRING, Gunnar 1964: An Eastern Turki-English Dialect Dictionary. Lund: CWK Gleerup.

JuDACHIN, K.K. 1965: Kirgizsko-russkij slovar'. Moscow.

KITSUDŌ, Kōichi 2011: "Two Chinese Buddhist Texts Written by Uighurs". In: Acta Orientalia Academiae Scientiarum. Hungaricae 64, 325-343.

Laut, Jens Peter 2011: "Mustafa İnan und das Suffix -inti”. In: Hoşsohbet Erika Glassen zu Ehren. Würzburg: Ergon Verlag, 195-219.

Li Gang 2016: "An Old Uighur Fragment in Alliterative Verses Preserved in the Turfan Museum". In: Studies on the Inner Asian Languages 31, 21-27.

Maue, Dieter 1996: Alttürkische Handschriften Teil 1: Dokumente in Brāhmī und tibetischer Schrift. Stuttgart: Franz Steiner Verlag.

Mirkamal, Aydar 2010: "The Uighur Madhyama Āgama Fragment Preserved in the Gest Collection of Princeton University Library". In: Kyoto University Linguistic Research 29, $1-26$.

RÁSONYI, László and BASKI, Imre 2007: Onomasticon Turcicum. Turkic Personal Names, III. Bloomington: Indiana University Denis Sinor Institute for Inner Asian Studies.

SWTF 1994-2018: Sanskrit-Wörterbuch der buddhistischen Texte aus den Turfan-Funden. Göttingen: Vandenhoek and Ruprecht.

UWN 2017: K. Röhrborn. Uighurisches Wörterbuch. Sprachmaterial der vorislamischen türkischen Texte aus Zentralasien - Neubearbeitung - II. Nomina - Pronomina - Partikeln. Band 2: aš - äžük. Stuttgart: Steiner Verlag.

UWV 2010: K. Röhrborn. Uigurisches Wörterbuch. Sprachmaterial der vorislamischen türkischen Texte aus Zentralasien - Neubearbeitung - I. Verben. Stuttgart: Steiner Verlag.

WiLKENS, Jens 2017: "The Old Uyghur translation of the Bieyi za ahanjing". In: The Old Uyghur Agama fragments preserved in the Sven Hedin collection, Stockholm, Turnhout: Brepols, 197-280.

ZiEmE, Peter 1991: Die Stabreimtexte der Uiguren. Studien zur altuigurischen Dichtung. Budapest: Akadémiai Kiadó.

„A Brāhmaṇa Painting from Bäzäklik in the Hermitage of St. Petersburg and Its Inscriptions“. In: T. Pang and S.-Chr. Raschmann and G. Winkelhane (edd.). Unknown Treasures of the Altaic World in Libraries, Archives and Museums. 53rd Annual Meeting of the Permanent International Altaistic Conference, Institute of Oriental Manuscripts, R[ussian] A[cademy of] S[ciences] St. Petersburg, July 25-30, 2010. Berlin: Klaus Schwarz Verlag 2013, 181-195.

„Paul Pelliot and tärim“. In: Journal of Sino-Western Communications 7 (2015), 147-257.

Zwischen Thron und Misthaufen. Die Geschichte von Anāthapiṇ̣̣ika in einer altuigurischen Blockdruck-Version, academia.edu 2017.

"Kaniska in the Old Turkic Tradition". In: Great Journeys across the Pamir Mountains. A Festschrift in Honor of Zhang Guangda on his Eighty-Fifth Birthday. Leiden-Boston: Brill 2018, 176-185. 